\title{
PEMBELAJARAN KEWIRAUSAHAAN DI PTAIN JAWA TIMUR: PERSPEKTIF STRATEGI PEMBELAJARAN
}

\author{
Salim Al Idrus \\ Fakultas Ekonomi Universitas Islam Negeri Maulana Malik Ibrahim Malang \\ Jalan Gajayana 50 Malang \\ E-mail : salim.alaydrus@yahoo.com
}

\begin{abstract}
Entrepreneurship education, as a local curriculum, is needed to enlarge and support the students' skill. So it is needed modification of conventional education method to obtain information about education strategy of entrepreneurship at Islamic State PTAIN Jawa Timur of East Java. Findings obtained from the study are (1) the education process of entrepreneurship subject in Islamic State PTAIN Jawa Timur of East Java is given by a master who has profession as a head of official functionary on fisheries institution in PTAIN Jawa Timur. He organizes the subject in a written summary that will be read in front of the class, (2) the class is started by giving the students real phenomenon to strengthened their view and it will be finished by giving them writing exercise or individual/group task; the students searching many literatures to be resumed. Lecturer is used as a media and the method used are lecture, discussion, and literature, (3) Creating students' interest into the real phenomenon in order to strengthened students' view. Pre-test and post-test given in written exercise or individual/group task will generate good studying motivation to each of the students and it also will increase interaction between lecturer and students on the subject studied.
\end{abstract}

Keywords : Kewirausahaan, strategi pembelajaran, PTAIN Jawa Timur

Salah satu mata kuliah di PTAIN Jawa Timur yang diarahkan untuk memperluas dan menunjang kebutuhan ketrampilan mahasiswa serta sekaligus sebagai profesi yaitu pembelajaran mata kuliah kewirausahaan. Dengan pendidikan kewirausahaan sebagai profesi diharapkan akan melahirkan para entrepreneur (wirausahawan), yaitu para sarjana yang mempunyai social responsibility untuk diupayakan dan dipersiapkan terbentuk menjadi inovator, entrepreneur yang mampu membuka lapangan kerja bagi orang lain, menciptakan nilai tambah, meningkatkan efisiensi dan produktivitas serta menciptakan keungggulan bersaing bagi bangsa Indonesia nantinya. (Idrus, 1999). Untuk menumbuhkembangkan wawasan kewirausahaan (entrepreneurship), khususnya bagi mahasiswa PTAIN Jawa Timur, maka efektifitas dalam proses pembelajaran, khususnya pembelajaran mata kuliah kewirausahaan perlu adanya kurikulum, silabus dan pengalaman belajar yang harus dipilih dan diracik, sehingga tujuan pembelajaran benar-benar dapat dicapai.

PTAIN Jawa Timur sebagai obyek penelitian, di mana salah satu hal yang cukup menarik dalam aplikasi pendidikan kewirausahaan yaitu tentang pelaksanaan pembelajaran mata kuliah Kewirausahaan yang masih bersifat konvensional. Di mana teori-teori yang disampaikan belum sepenuhnya diarahkan untuk membuka wawasan lebih jauh tentang kenyataan yang terjadi pada dunia bisnis saat ini, bahkan belum diterapkannya bagaimana membaca peluang serta menyikapi keadaan lingkungan, sehingga dapat mengambil manfaat dan keuntungan ekonomis dari keadaan di lapangan sesuai dengan kemampuan masingmasing mahasiswa. Hal ini dilakukan dengan maksud setidak-tidaknya dapat menggali 
potensi dan wawasan yang dimiliki mahasiswa guna menumbuhkembangkan wawasan kewirausahaan, khususnya dalam bidang kewirausahaan tertentu. Perlu dikemukakan bahwa untuk menyeimbangkan wawasan keilmuan dengan wawasan Aplikasi praktis dalam bidang bisnis dan manajemen umumnya, serta kewirausahaan pada khususnya, perlu juga diupayakan salah satu cara yaitu dengan menimba pengalaman langsung dari para praktisi yang berhubungan langsung dengan pengembangan wirausaha tertentu, seperti dari para wirausahawan yang telah berhasil dan praktisi perbankan yang menangani pembinaan usaha kecil dan menengah, serta pihak-pihak lain yang terkait. Oleh karena itu mahasiswa yang mengikuti pembelajaran mata kuliah Kewirausahaan diharapkan tidak hanya menguasai ilmu pendidikan kewirausahaan secara teoritik saja, tetapi juga sekaligus dituntut sanggup menerapkannya. Dengan demikian, diharapkan mereka menjadi sarjana yang siap kerja, khususnya dalam bidang kewirausahaan tertentu.

Permasalahan tersebut pada dasarnya berpusat pada bagaimanakah cara mengelola pembelajarannya secara efektif dan efisien. Untuk menjawab pertanyaan tersebut diperlukan suatu kesepakatan mengenai makna pembelajaran. Degeng (1989) mengartikan pembelajaran sebagai upaya membelajarkan pembelajar. Upaya-upaya yang dilakukan dapat berupa melakukan analisis tujuan dan karakteristik bidang studi dan pembelajar, analisis sumber belajar, menetapkan strategi pengorganisasian isi pembelajaran, menetapkan strategi penyampaian pembelajaran, menetapkan strategi pengelolaan pembelajaran, dan menetapkan prosedur pengukuran hasil pembelajaran (Degeng dan Miarso, 1990). Oleh karena itu setiap pengajar harus memiliki ketrampilan dalam memilih strategi pembelajaran untuk setiap jenis kegiatan pembelajaran, sebab pembelajaran menaruh perhatian pada bagaimana mengupayakan agar pembelajar belajar (membelajarkan pembelajar) bukan pada apa yang dipelajari pembelajar. Dengan demikian pembelajaran lebih menekankan pada cara-cara yang dilakukan oleh pengajar untuk mencapai tujuan yang telah ditentukan. Gilstrap dan Martin (1975) juga mengatakan bahwa peran pengajar lebih erat kaitannya dengan keberhasilan pembelajaran, terutama berkenaan dengan kemampuan pengajar dalam menetapkan strategi pembelajaran.

Pendidikan kewirausahaan sebagai obyek penelitian telah diteliti oleh beberapa ahli. Idrus (1999) mengkaji masalah strategi pengembangan kewirausahaan dan peranan perguruan tinggi dimana perguruan tinggi yang strategis perlu diaktifkan untuk mendorong percepatan perluasan kesempatan kerja melalui pengembangan pelaku-pelaku ekonomi baru (entrepreneur) yang terampil dan mempunyai teknologi maju, berusia muda yang produktif, kreatif dan berdaya saing. Alma (1999) mengkaji tentang memasyarakatkan pengetahuan kewirausahaan dalam memeacahkan persoalan tenaga kerja dimana pilihan masa depan buat suatu negara dalam mengatasi persoalan tenaga kerja yang makin banyak menganggur tiada lain dengan membuka lapangan wira usaha dan memasyarakatkan pengetahuan kewirausahaan melalui berbagai buku dan media. Natsir (1999) mengkaji masalah pemahaman etika kerja (Islam) terhadap tingkah laku kewirausahaan dimana dalam proses pembangunan para ahli ekonomi mengakui akan pentingnya peranan tingkah laku kewirausahaan dalam memajukan perkembangan ekonomi suatu bangsa. Tinggi rendahnya tingkah laku kewirausahaan tersebut berkaitan dengan berbagai faktor. Salah satu faktor utama adalah dasar keyakinan, pandangan hidup atau agama yang menjadi daya pendorong tingkah laku, selain dipengaruhi oleh berbagai faktor yang berkaitan secara kompleks baik faktor budaya, agama maupun faktor struktur sosial. Soemanto (1984) mengkaji tentang pendidikan dan persiapan manusia wiraswasta di lingkungan sekolah dan masyarakat di mana 
banyak orang yang ingin hidup maju dan berhasil dengan menumpukan sepenuhnya harapan mereka kepada sekolah-sekolah, baik di kalangan orang tua maupun di kalangan generasi muda yang mempunyai harapan besar agar melalui sekolah akan diperoleh nasib yang lebih baik, kemajuan dan kesuksesan dalam hdup. Di samping itu banyak pula orang yang ingin hidup maju dan berhasil dengan menempuh pengalaman-pengalaman praktis di lingkungan masyarakat. Lupiyoadi dan Wacik (1998) mengkaji masalah wawasan kewirausahaan dalam membangun kecenderungan mental, khususnya di kalangan perguruan tinggi, yaitu menyadarkan pada mahasiswa bahwa kewirausahaan bisa dipelajari dengan mengajak belajar berproses, mengajak menyelami karakter dan motivasi wirausaha, membuka cakrawala fenomena bisnis dan bagaimana berhitung untuk menjadi wirausaha, mengajak menimbang dan memilih berbagai bentuk usaha dan bagaimana memulainya.

Dari sekian banyak studi mengenai pendidikan kewirausahaan, masalah upaya-upaya pengembangan kewirausahaan telah disinggung di dalamnya sebagai bagian dari obyek penelitian. Adapun bagaimanakah strategi pembelajaran kewirausahaan, sepanjang literatur yang penulis telaah belum dikaji secara spesifik. Oleh karena itu perspektif strategi pembelajaran mata kuliah Kewirausahaan yang merupakan salah satu kurikulum lokal di PTAIN Jawa Timur dipandang perlu untuk diteliti dalam rangka menggali informasi tentang Aplikasi pendidikan kewirausahaan di lapangan dan mengungkap serta memperkaya khazanah budaya keilmuan bangasa Indonesia khususnya di lingkungan Perguruan Tinggi.

Berdasarkan latar belakang tersebut, rumusan masalah penelitian ini adalah : Bagaimana strategi pembelajaran mata kuliah Kewirausahaan sebagai salah satu alternatif untuk menumbuhkembangkan wawasan kewirausahaan bagi mahasiswa PTAIN Jawa Timur? Rumusan masalah tersebut dapat dijabarkan sebagai berikut : (1) Bagaimanakah strategi pengorganisasian pembelajaran mata kuliah kewirausahaan di PTAIN Jawa Timur? (2) Bagaimanakah straategi penyampaian pembelajaran mata kuliah Kewirausahaan di PTAIN Jawa Timur? (3) Bagaimanakah strategi pengelolaan pembelajaran mata kuliah Kewirausahaan di PTAIN Jawa Timur?

Pembelajaran kewirausahaan dapat dimulai dengan membaca kemampuan dan potensi diri, potensi lingkungan sekitar yang kemudian diolah melalui percobaan empirik sehingga menjadi peluang bisnis yang menguntungkan. Asy'ari (1996) mengungkapkan perlu adanya beberapa tahapan yang dilakukan sehubungan dengan pembelajaran kewirausahaan tersebut yaitu :

\section{Tahap pengenalan diri}

Melalui pengenalan diri secara intens seseorang dapat mengenali kekuatan-kekuatan dan kelemahan-kelemahan yang ada dalam dirinya. Keseimbangan dalam mengenali dan memahami dirinya baik dari sisi kekuatan dan kelemahan, kebaikan dan keburukan adalah mutlak diperlukan karena tanpa keseimbangan tersebut dapat menjebak seseorang ke sisi yang tidak menguntungkan. Setiap orang mempunyai kemapuan sendiri-sendiri dan antara yang satu dengan yang lainnya berbeda. Perbedaan kemampuan harus dikenali dengan baik dan harus disadari agar dapat dijalin kekuatan sinergik dalam tim kerja dengan menggabungkan semua potensi-potensi yang ada untuk saling melengkapi dan dikembangkan menjadi kekuatan untuk memajukan usahanya.

\section{Tahap pengenalan potensi ekonomi, lingkungan hidup, dan lingkungan masyarakat}


Karena di dalam lingkungan hidup dan lingkungan masyarakat terkandung potensi ekonomi yang besar, yang satu dengan yang lainnya berbeda maka setiap usaha selalu berhubungan dengan ruang, waktu dan lingkungan tersebut. Pengenalan terhadap potensi ekonomis dari lingkungan perlu dilakukan secara mendalam dari berbagai segi baik dari sumber daya alam, sumber daya manusia, situasi pasar, persaingan dan kualitas produksi serta teknologi, bahan baku yang kaitannya dengan kegiatan ekonomi serta tingkat pertumbuhannya.

\section{Tindakan nyata dengan percobaan empirik}

Berdasarkan pengenalan yang mendalam terhadap potensi ekonomi, baik yang tersimpan dalam kemampuan diri, maupun potensi yang ada dalam lingkungan hidup, kemudian dilakukannya perhitungan ekonomi (studi kelayakan), maka selanjutnya pilihan usaha harus ditetapkan dan diikuti dengan tindakan nyata melalui percobaan empirik tersebut. Percobaan empirik bisa dilakukan dengan cara magang kerja dalam dunia kerja nyata. Magang merupakan cara pendalaman usaha yang paling kecil resikonya. Akan tetapi biasanya dalam proses magang, seseorang akan sulit memperoleh pengalaman yang diperlukannya, yang menjadi kunci sukses usaha tempat magang. Disini diperlukan kecerdasan dan kejujuran serta sikap yang baik sehingga kunci sukses dapat dipahami tanpa merugikan pihak lain.

\section{Tahap pengembangan usaha}

Hal ini dapat dilakukan setelah tahap percobaan empirik menunjukkan hasil positif. Biasanya hasil yang positif tersebut dicari dengan beberapa kali percobaan empirik, sebagai proses pendalaman terhadap struktur usahanya. Pengembangan usaha dapat dilakukan secara vertikal dan horisontal akan tetapi sebaiknya perkembangan vertikal lebih didahulukan kemudian jika sudah dicapai titik maksimum sesuai dengan kemampuan yang ada baru dikembangkan secara horisontal. Hal ini disebabkan pengembangan usaha secara horisontal dengan membuka usaha-usaha baru yang lain dari usaha yang sudah dikembangkannya terdahulu dalam prosesnya ternyata dimulai dari awal lagi. Biasanya pengembangan suatu usaha seringkali tidak diikuti dengan kecepatan pengembangan manajemen usahanya. Oleh karena itu sejak awal usahanya dirintis sudah seharusnya mulai dipikirkan mengenai pengembangan manajemen dengan cara mengembangkan kemampuan profesional sumber daya manusianya.

Jadi ketika seseorang masuk dalam dunia wirausaha maka ia akan berhadapan dengan serangkaian kegiatan usaha yang terencana untuk memperoleh profit dan dalam serangkaian kegiatan usaha itu paling tidak ada 4 (empat) bidang kegiatan yang penting yang harus dikendalikan oleh seorang wirausaha yang satu dengan lainnya merupakan kesatuan yang tidak dapat dipisahkan yaitu: (1) Bidang produksi, baik berupa barang maupun jasa. Sebuah produk di samping diperlukan, ia juga harus memenuhi standar tertentu sehingga pihak konsumen tidak dirugikan. Tuntutan untuk meningkatkan kualitas sehingga pemakainya puas dan mendapatkan keuntungan pada dasarnya bukan hanya tuntutan ekonomi, tetapi juga merupakan panggilan agama untuk berbaik-baik kepada sesamanya. (2) Bidang pemasaran. Pemasaran merupakan kegiatan mempengaruhi konsumen agar mau membeli produk yang ditawarkan. Kegiatan pemasaran harus mampu meningkatkan penjualan sesuai dengan jumlah yang diproduksi, jika tidak dipastikan perusahaan akan mengalami kerugian. Keseimbangan antara kemampuan memproduksi 
barang/jasa dan kemampuan menjualnya harus tetap dijaga dan peningkatannya harus juga didasarkan pada peningkatan keseimbangan antara keduanya. (3) Bidang keuangan. Perusahaan ibarat tubuh maka keuangan adalah darahnya. Arus keuangan yang lancar untuk membiayai segala kegiatan perusahaan merupakan kunci kelancaran bisnisnya. (4) Bidang sumber daya manusia. Kemajuan suatu perusahaan akan ditentukan sepenuhnya oleh kualitas sumber daya manusianya. Sebuah perusahaan yang kualitas sumber daya manusianya rendah akan mengalami kesulitan berkembang dan memenangkan persaingan. Rencana pengembangan suatu usaha harus dilakukan sesuai dengan perkembangan kualitas dan sikap profesionalisme dari sumber daya manusianya. (Asy'ari, 1996)

\section{Taksonomi Variabel Pembelajaran}

Hasil pembelajaran yang didefinisikan mencakup semua efek yang dapat dijadikan sebagai indikator tentang nilai dari penggunaan metode pembelajaran dibawah kondisi pembelajaran yang berbeda adalah bisa berupa hasil nyata (actual outcome) dan hasil yang diinginkan (desired outcomes). Actual outcomes adalah hasil yang nyata dicapari dari penggunaan suatu metode dibawah kondisi tertentu, sedangkan desired outcomes adalah tujuan yang ingin dicapai, yang sering mempengaruhi keputusan perancang pembelajaran dalam melakukan pilihan metode yang sebaiknya digunakan. Klasifikasi variabel-variabel pembelajaran tersebut secara keseluruhan seperti ditunjukkan pada gambar 1 berikut ini:

\begin{tabular}{|c|c|c|c|}
\hline Kondisi & $\begin{array}{l}\text { Tujuan dan } \\
\text { karakteristik } \\
\text { bidang studi }\end{array}$ & $\begin{array}{l}\text { Kendala dan } \\
\text { karakteristik } \\
\text { bidang studi }\end{array}$ & $\begin{array}{l}\text { Karakteristik } \\
\text { pembelajar }\end{array}$ \\
\hline Metode & 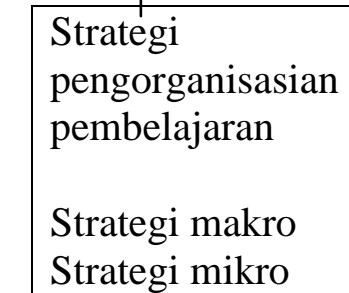 & $\begin{array}{l}\text { Strategi } \\
\text { penyampaian } \\
\text { pembelajaran }\end{array}$ & $\begin{array}{l}\text { Strategi } \\
\text { pengelolaan } \\
\text { pembelajaran }\end{array}$ \\
\hline Hasil & \multicolumn{3}{|c|}{ Keefektifan, efisiensi dan daya tarik pembelajaran. } \\
\hline
\end{tabular}

Sumber : Diolah dari Reigeluth (1983) dan Degeng (1989)

\section{Strategi Pengorganisasian Pembelajaran}

Strategi pengorganisasian pembelajaran dibedakan menjadi dua (2) jenis, yaitu strategi pengorganisasian pada tingkat mikro dan tingkat makro. Strategi mikro adalah mengacu kepada metode untuk mengorganisasi ini pembelajaran yang berkisar pada satu konsep atau prosedur atau prinsip. Sedangkan strategi makro mengacu kepada metode untuk mengorganisasi isi pembelajaran yang melibatkan lebih dari satu konsep atau prosedur atau prinsip. 
Strategi makro adalah berurusan dengan bagaimana memilih, menata urutan, membuat sintesis dan rangkuman isi pembelajaran (apakah itu berupa konsep, prosedur, atau prinsip) yang saling berkaitan. Pemilihan ini berdasarkan tujuan pembelajaranyang ingin dicapai, mengacu kepada penataan konsep-konsep yang diperlukan untuk mencapai tujuan itu. Penataan urutan isi mengacu kepada keputusan tentang bagaimana cara menata atau menentukan urutan konsep, prosedur atau prinsip-prinsip, hingga tampak keterkaitannya dan menjadi mudah dipahami

\section{Strategi Penyampaian Pembelajaran}

Strategi penyampaian pembelajaran merupakan komponen variabel metode untuk melaksanakan proses pembelajaran. Strategi ini memiliki dua (2) fungsi, yaitu : (1) menyampaikan isi pembelajaran kepada pembelajar dan (2) menyediakan informasi atau bahan-bahan yang diperlukan pembelajar untuk menampilkan unjuk kerja (seperti latihan dan tes). Secara lengkap ada 3 (tiga) komponen yang perlu diperhatikan dalam mendiskripsikan strategi penyampaian pembelajaran, yaitu; (a) Media pembelajaran, (b) Interaksi pembelajar dengan media, dan (c) Bentuk belajar mengajar.

\section{Strategi Pengelolaan Pembelajaran.}

Strategi pengelolaan pembelajaran merupakan komponen variabel metode pembelajaran yang berkenaan dengan bagaimana menata interaksi antara pembelajar dengan variabel-variabel metode pembelajaran lainnya. Strategi ini berkaitan dengan pengambilan keputusan tentang strategi pengorganisasian dan strategi penyampaian tertentu yang digunakan selama proses pembelajaran. Paling sedikit ada 4 (empat) klasifikasi penting variabel strategi pengelolaan pembelajaran yang meliputi : (a) Penjadwalan penggunaan strategi pembelajaran, (b) Pembuatan catatan kemajuan belajar pembelajar, (c) Pengelolaan motivasional, dan (d) Kontrol belajar.

\section{METODE}

Penelitian ini menggunakan studi kasus. Metode studi kasus penelitian ini bertujuan untuk memahami tentang strategi pembelajaran mata kuliah Kewirausahaan di PTAIN Jawa Timur yang selanjutnya untuk memahami wawasan Kewirausahaan bagi mahasiswa yang mengikuti pembelajaran mata kuliah Kewirausahaan di PTAIN Jawa Timur. Penelitian dengan pendekatan studi kasus tersebut menggunakan Rancangan yang dikemukakan oleh Bogdan dan Biklen (1982 : 59) yang disajikan dalam bentuk funnel (cerobong) yang melukiskan proses penelitian yang berawal dari eksplorasi yang bersifat luas, kemudian berlanjut dengan beraktifitas pengumpulan dan analisis data yang lebih menyempit dan terarah pada suatu topik tertentu.

Pada mulanya peneliti menjajaki pengajar mata kuliah Kewirausahaan sebagai sumber data utama (informan utama), kemudian menjajaki 3 (tiga) orang mahasiswa yang representatif dan dianggap dapat menguasai dan memberikan informasi tentang pembelajaran mata kuliah Kewirausahaan di PTAIN Jawa Timur, lalu mencari lokasi yang dipandang sesuai dengan maksud pengkajian penelitian, selanjutnya mengembangkan jaringan yang lebih luas untuk menemukan kemungkinan sumber data. Penjelasan lebih lanjut tentang rancangan penelitian bentuk funnel adalah sebagaimana yang dikemukakan oleh Owens (1987 : 186) sebagai berikut : 
Gambar 2:

Rancangan Penelitian Bentuk Funnel

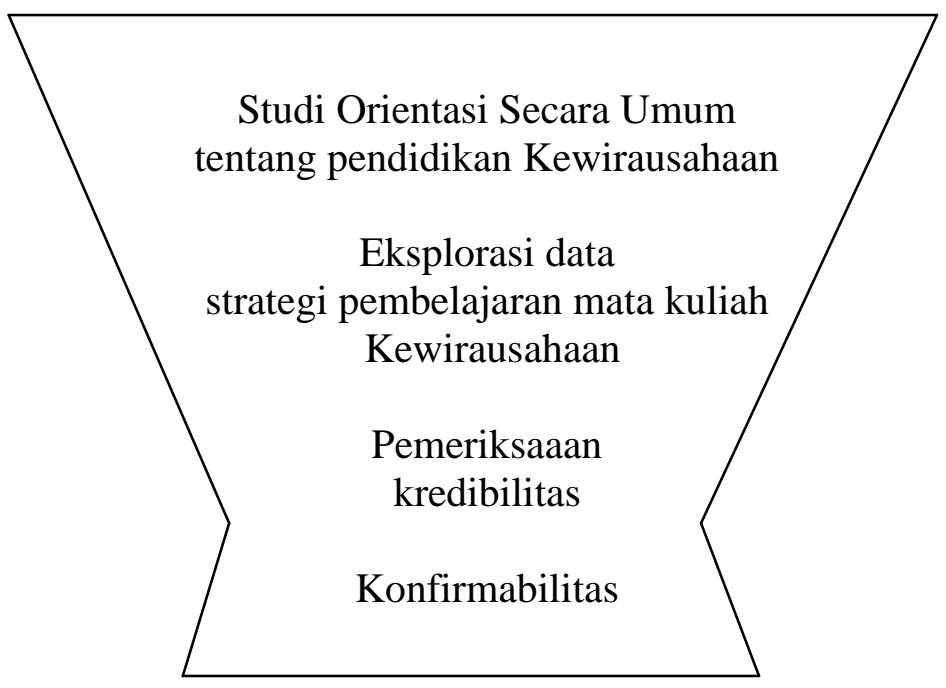

Sumber : Owens (1987)

Dengan bentuk funnel tersebut, penelitian ini berusaha memperoleh penjelasan yang dapat membantu merekonstruksi dan mengklasifikasi kenyataan dan mengintegrasikan data ke dalam seperangkat konstruk teoritik.

\section{Definisi Operasional}

PTAIN Jawa Timur (Perguruan Tinggi Agama Islam Negeri di Jawa Timur terdiri dari : (a) Universitas Islam Negeri (UIN) Malang, (b) Institut Agama Islam Negeri (IAIN) Surabaya, (c) Sekolah Tinggi Agama Islam Negeri (STAIN) Pamekasan, (d) Sekolah Tinggi Agama Islam Negeri (STAIN) Jember, (e) Sekolah Tinggi Agama Islam Negeri (STAIN) Kediri, (f) Sekolah Tinggi Agama Islam Negeri (STAIN) Tulung Agung, dan (g) Sekolah Tinggi Agama Islam Negeri (STAIN) Ponogoro. Namun dalam penelitian ini yang diambil sebagai obyek penelitian adalah PTAIN kelompok STAIN karena jumlahnya paling banyak dan yang diambil sebagai sampel penelitiannya adalah STAIN Pamekasan, STAIN Jember dan STAIN Kediri (multi situs tapal kuda dan dengan berbagai pertimbangan aktivitas bisnis yang cenderung lebih dinamis).

\section{Teknik Pengumpulan Data}

Teknik pengumpulan data dalam penelitian ini dilakukan melalui tiga (3) tahapan. Pertama, tahap orientasi. Dalam tahap ini peneliti mengumpulkan data secara umum tentang 
Aplikasi pendidikan Kewirausahaan yaitu tentang perspektif strategi pembelajaran mata kuliah Kewirausahaan untuk dicari hal-hal yang menonjol, menarik dan penting untuk diteliti lebih mendalam. Kedua, eksplorasi pengumpulan data Pada tahap ini pengumpulan data dilakukan lebih terarah sesuai dengan fokus penelitian serta mengetahui sumber data atau informan yang kompeten dan mempunyai pengetahuan yang cukup tentang hal yang akan diteliti. Dalam hal ini peneliti telah mulai menggunakan teknil snowball sampling. Ketiga, peneliti melakukan penelitian terfokus pada minggu yaitu mengembangkan penelitian eksploratif kepada fokus penelitian. Dalam tahapan-tahapan tersebut teknik pengumpulan data yang digunakan meliputi : (a) wawancara mendalam, (b) pengamatan peran serta dan (c) dokumentasi. Ketiga teknik tersebut dilakukan berulang-ulang sesuai dengan persoalan yang muncul pada saat tertentu.

\section{Informan Penelitian}

Dalam mencari data dari informan, Spradley (1979) memberikan kriteria awal untuk mendekati informan di antaranya : (1) informan yang cukup lama dan intensif menyatu dengan medan kegiatan yang menjadi sasaran peneliti, (2) informan yang masih aktif terlibat dalam lingkungan kegiatan yang menjadi sasaran peneliti, (3) informan yang banyak mempunyai waktu untuk dimintai informasi oleh peneliti, (4) informan yang tidak banyak mengkemas informasi, tetapi relatif memberikan informasi yang sebenarnya, (5) informan yang tergolong asing bagi peneliti, sehingga terkesan sebagai dosen baru. Hal ini juga disebutkan oleh Sutopo (1998:16) bahwa penggunaan teknik purposive sampling adalah peneliti cenderung memilih informan awal yang dianggap tahu dan dapat dipercaya untuk menjadi sumber data yang mantap serta mengetahui masalahnya secara mendalam yaitu pengajar mata kuliah Kewirausahaan.

Untuk mendapatkan informasi yang relevan dan urgen tersebut, maka peneliti melakukannnya melakukan wawancara dan observasi dengan menggunakan teknik sampling bola salju (snowball sampling technique) (Bagdan dan Biklen, 1982:66). Teknik snowball sampling yang diibaratkan sebagai bola salju yang terus menggelinding semakin lama semakin besar dalam arti memperoleh informasi secara terus menerus dan baru akan berhenti setelah informasi yang diperoleh peneliti memiliki kesamaan antara satu informan dengan informan yang lainnya, sehingga mengalami kejenuhan informasi dan tidak berkembang lagi (Moleong, 1990, Dimyati, 1990). Adapun informan dalam penelitian ini berjumlah 4 (empat) orang diantaranya pengajar mata kuliah Kewirausahaan, wakil mahasiswa yang representatif sebaganyak 3 (tiga) orang yang mengikuti pembelajaran mata kuliah Kewirausahaan yang dianggap menguasai dan dapat memberikan penjelasan tentang pelaksanaan pembelajaran mata kuliah Kewirausahaan di PTAIN Jawa Timur.

\section{Pengorganisasian, Pengolahan dan Analisis Data.}

Pengorganisasian data dilakukan peneliti bersamaan dengan pengumpulan data yang dikerjakan dengan cara memilah dan mengelompokkannya berdasarkan klasifikasi data. Pengelolaannya dilakukan bersamaan dengan pengorganisasiannya melalui kategori koding dengan tahapan (1) menelusuri data, guna melihat kemungkinan keteraturan pola, tema atau topik dan (2) mencatat kata-kata, ungkapan-ungkapan guna menampilkan pola, tema atau topik tersebut. Kata-kata atau ungkapan-ungkapan ini disebut sebagai kategori koding (Bogdan dan Biklen, 1982 :156).

Bogdan dan Biklen (1982 : 16-17) memberikan petunjuk tentang skema koding dalam kategori koding. Skema koding dalam kategori koding penelitian diperoleh dari respon informan 
terhadap pertanyaan peneliti, pengamatan, dokumentasi serta kajian teoritik yang dikumpulkan selama berlangsungnya penelitian. Kategori koding kemudian disusun dalam suatu kelompok kategori koding dan suatu unit dapat dikode dengan lebih dari satu kategori kode maupun kelompok. Langkah awal dalam pengorganisasian dalam penelitian ini dikerjakan melalui memeriksa semua halaman bahan-bahan dan memberinya nomor urut serta berkesinambungan. Penomoran dilakukan berdasarkan kronologis perolehan data. Langkah berikutnya adalah membaca catatan bahan-bahan dan sementara itu pengembangan kategori koding pendahuluan dimulai. Langkah akhir kegiatan ini adalah mencari dan menemukan pola pemilihan data secara fisik yang sesuai dengan kemampuan peneliti.

Teknik analisa data yang digunakan dalam penelitian ini adalah "kualitatif diskriptif" yang bermaksud untuk menjawab pertanyaan-pertanyaan yang dirumuskan dalam penelitian. Proses analisa data penelitian kualitatif dalam prakteknya tidaklah dapat dipisah-pisahkan dengan proses pengumpulan data. Kedua kegiatan ini berjalan secara serempak yaitu kegiatan analisis data yang dikerjakan bersamaan dengan pengumpulan data dan dilanjutkan setelah pengumpulan data selesai. (Spradley, 1979;Bagdan dan Biklen,1982). Dengan demikian secara teoritis analisis dan pengumpulan data dilaksanakan secara berulang-ulang guna memecahkan masalah (Soegiyanto, 1989). Salah satu cara yang disarankan oleh Miles dan Huberman (1984:21-23) dalam melakukan analisis data adalah melalui 3 (tiga) tahapan untuk dikerjakan, yaitu (1) data reduction, (2) data display, dan (3) conclusioan drawing/ferification. Kredibilitas data bertujuan untuk membuktikan bahwa apa yang diamati oleh peneliti sesuai dengan apa yang sesungguhnya ada dalam dunia kenyataan dan sesuai dengan yang sebenarnya terjadi. Kriteria kredibilitas (validitas ) digunakan untuk memenuhi bahwa data dan informasi yang dikumpulkan peneliti harus mengandung nilai kebenaran, baik bagi pembaca maupun bagi informan yang diteliti (Soegianto, 1989).

Teknik yang digunakan oleh peneliti dalam upaya memperoleh data yang valid (soheh) meliputi : (a) Persistent observation yaitu mengadakan observasi secara terus menerus terhadap informan yang diteliti guna memahami gejala lebih mendlam sehingga mengetahui aspek yang penting, relevan dan terfokus pada strategi pembelajaran mata kuliah Kewirausahaan. (b) Triangulation : Data dicek keabsahannya dengan memanfaakan berbagai sumber diluar data tersebut sebagai bahan perbandingan. Untuk menanggulangi kesalahan-kesalahan di dalam mengkonseptualisasikan hasil penelitian ini, maka pengumpulan data dan interpretasinya atau informasi yang telah ditulis dalam bentuk penelitian ini dikonfirmasikan dengan berbagai pihak guna ikut mereview proses penelitian yang selanjutnya untuk menilai hasil penelitian itu sendiri.

\section{PEMBAHASAN HASIL PENELITIAN \\ Strategi Pembelajaran Mata Kuliah Kewirausahaan di PTAIN Jawa Timur: Perspektif pengorganisasian pembelajaran}

Dalam penelitian ini ditemukan bahwa pengajar mata kuliah Kewirausahaan di PTAIN Jawa Timur membuat pengorganisasian isi materi yang akan diajarkan, dengan membuat ringkasan secara tertulis dengan tangan dan tidak digandakan untuk disebarluaskan, tapi didiktekan (bila perlu). Pengajar mata kuliah tidak membuat perubahan urutan pokok bahasanpokok bahasan yang sudah ada dalam silabus. Dalam kaitannya dengan perlunya pengorganisasian isi silabus mata kuliah Kewirausahaan di PTAIN Jawa Timur dalam upaya strategi pengembangan kewirausahaan dan peranan perguruan tinggi hanya terjadi dengan seleksi, reformasi, revisi dari pakar, kemudian terhadap pemikiran para pakar terdahulu dan bukan sekali-kali untuk maksud mengabaikannya sama sekali. Oleh sebab itu pengorganisasian 
kembali isi silabus secara tertulis dan digandakan/disebar luaskan masih tetap diperlukan. Sehubungan dengan pengorganisasian kembali isi silabus, Alma (1999) dalam bukunya tentang Kewirausahaan-Panduan Perkuliahan menawarkan pula reformasi, revisi tentang pemahaman kewirausahaan untuk ruang lingkup kuliah di perguruan tinggi dengan isi pokok bahasan-pokok bahasan sebagai berikut : (1) Pendahuluan, (2) Sifat-sifat yang perlu dimiliki wirausaha, (3) kepribadian, temperamen dan watak, (4) Meningkatkan produktivitas usaha melalui motivasi, (5) Eksploitasi imajinasi dan intuisi untuk kemajuan usaha, (6) Jalan menuju wirausaha sukses, (7) Menjual, kegiatan dasar wirausaha, (8) Profil usaha, (9) Perencanaan usaha, (10) Mutiara kegiatan wirausaha dalam ajaran Islam.

\section{Strategi Pembelajaran Mata Kuliah Kewirausahaan di PTAIN Jawa Timur: Perspektif Penyampaian Pembelajaran.}

Temuan penelitian dalam masalah penyampaian pembelajaran mata kuliah Kewirausahaan di PTAIN Jawa Timur di mana pengajar mata kuliah memulai pembelajaran dengan memberikan fenomena-fenomena berpikir terhadap persoalan-persoalan yang terjadi dalam kehidupan masyarakat yang berkenaan dengan lingkup kewirausahaan dengan maksud untuk penguatan wawasan terhadap materi yang akan disampaikan berikutnya dan juga untuk motif memotivasi mahasiswa berpikir atau memotivasi ketertarikan berpikir mahasiswa terhadap materi yang akan disampaikan nantinya. Demikian pula dalam hal menutup pembelajaran, pengajar mata kuliah senantiasa memberikan soal-soal tertulis tentang topik materi yang telah disampaikan ataupun tugas-tugas individu/ kelompok untuk membuat ringkasan dari sumbersumber literatur yang dianjurkan. Model pembelajaran yang digunakan adalah konvensional/tradisional dengan mentransfer ilmu/materi dengan metode ceramah. Media pembelajaran yang digunakan adalah orang (pengajar), sedangkan metode yang digunakan meliputi ceramah dan kadang diskusi.

Pengajar mata kuliah kewirausahaan di PTAIN Jawa Timur di dalam penyampaian pembelajarannya lebih dominan menggunakan media orang (pengajar) dengan maksud untuk terciptanya tindak belajar ataupun ketertarikan mahasiswa yang banyak dipengaruhi prinsip bahwa pengajar adalah personifikasi dari ilmu yang disampaikan dan lebih banyak mengetahui, walaupun berdasarkan pengamatan peneliti justru terjadi sebaliknya, dimana pembelajaran mata kuliah yang disampaikan dengan menonton bermedia orang (pengajar) dapat membuat mahasiswa bosan/jenuh, hal ini nampak dari kurang/tidak adanya lontaran-lontaran pertanyaan sebagai antusias balik dari mahasiswa atas materi yang disampaikan. Oleh karena itu perlu diupayakan modifikasi jenis media yang digunakan, seperti : rekaman audio, rekaman video, simulasi dan permainan peran dan sebagainya untuk lebih memotivasi mahasiswa dalam belajar.

Dilihat dari sudut motivasi belajar, maka pengaruh motivasi belajar dan mengajar perlu diciptakan antara mahasiswa dan pengajar mata kuliah di PTAIN Jawa Timur, hal ini tercipta apabila adanya kesamaan karakteristik antara mahasiswa dengan media (pengajar) untuk suatu maksud tujuan pembelajaran tertentu. Demikian pula sebagaimana yang diungkapkan oleh Degeng (1989:145) bahwa semakin dekat kesamaan karakteristik pembelajar (mahasiswa) dengan media yang digunakan, maka semakin tinggi pengaruh motivasional yang bisa ditimbulkan oleh media itu. Dengan demikian, strategi penyampaian pembelajaran mata kuliah Kewirausahaan bermedia orang (pengajar) saja cenderung belum dapat menimbulkan motivasional bagi mahasiswa untuk belajar dan bagi pengajar untuk mengajar karena belum adanya kesamaan karakteristik diantaranya keduanya yaitu pencarian/pengembangan/pengayaan ilmu. 
Ditinjau dari aspek motivasional yang ditimbulkan, memang media orang (pengajar) dapat mempengaruhi motivasi belajar mahasiswa, tetapi belum memadai. Dan ditinjau dari aspek model pembelajaran yang konvensional/tradisional yang digunakan, maka masih diperlukan suatu inovasi, karena model konvensional/tradisional tersebut adalah suatu bentuk pentransferan ilmu dengan ceramah yang disampaikan secara lisan untuk memperoleh suatu informasi tentang suatu pokok persoalan tertentu. Degeng (1989) menyatakan bahwa untuk membentuk suatu kesatuan strategi penyampaian pembelajaran yang efektif harus berpijak pada tujuan khusus pembelajaran, karakteristik si belajar serta kendala yang secara nyata ada.

Dengan demikian strategi penyampaian pembelajaran mata kuliah Kewirausahaan di PTAIN Jawa Timur, selain harus mempertimbangkan kesamaan karakteristik mahasiswa dan pengajar, juga harus mempertimbangkan tujuan khusus pembelajaran bab/sub bab yang disampaikan, kemudian karakteristik bidang kajian bab/sub bab, dan perkembangan jiwa/sikap mahasiswa, sehingga memudahkan dalam proses pembelajaran, serta menetapkan model pembelajaran dan metode yang sesuai dengan isi materi kuliah. Berdasarkan pada temuan penelitian tentang strategi penyampaian pembelajaran mata kuliah Kewirausahaan di PTAIN Jawa Timur dan pendapat Degeng di atas, maka strategi penyampaian pembelajaran mata kuliah kewirausahaan di PTAIN Jawa Timur perlu diadakan inovasi di antaranya strategi penyampaian pembelajaran pada pokok bahasanpokok bahasan tertentu, kemudian metode yang ditawarkan serta media yang digunakan, yaitu sebagaimana disajikan pada tabel berikut :

Tabel 1:

Inovasi Strategi Penyampaian Pembelajaran

\begin{tabular}{|l|l|l|}
\hline $\begin{array}{l}\text { Bab/Pokok } \\
\text { bahasan }\end{array}$ & Metode yang Ditawarkan & Media yang Ditawarkan \\
\hline Peluang Usaha & $\begin{array}{l}\text { - Ceramah } \\
\text { - Karya wisata } \\
\text { - Tanya jawab } \\
\text { - Diskusi }\end{array}$ & $\begin{array}{l}\text { - Buku Ajar } \\
\text { - Rekaman Audio }\end{array}$ \\
\hline Memulai & - Ceramah & - Rekaman Video \\
Usaha & - Karya wisata & - Buku Ajar \\
& - Kerja Lapangan & - Rekaman Audio \\
& - Tanya Jawab & - Rekaman Video \\
& - Studi kasus & - Simulasi \& Permainan Peran \\
\hline Pembiayaan & - Ceramah & - Buku Ajar \\
Sebuah Usaha & - Latihan & - Transparan \\
& - Studi Kasus & - Rekaman Video \\
\hline Manajemen & - Ceramah & - Buku Ajar \\
& - Pemberian tugas & - Potret/Slide \\
& - Studi Kasus & - Transparan \\
& - Karya Wisata & - Rekaman Video \\
& & - Simulasi \& Permainan Peran \\
\hline
\end{tabular}

Sumber: Data diolah 
Pembahasan temuan penelitian tentang strategi penyampaian pembelajaran mata kuliah Kewirausahaan di PTAIN Jawa Timur tersebut dapat disimpulkan bahwa dalam penyampaian pembelajarannya, pengajar mata kuliah seharusnya mempertimbangkan bidang kajian bab/pokok bahasan, tujuan pembelajaran, perkembangan jiwa/sikap mahasiswa atau karakteristik dan batas waktu yang akan digunakan, agar media, metode yang dipilih/ditetapkan sesuai dengan bidang kajian bab/pokok bahasan dan dapat mencapai tujuan pembelajaran yang lebih efektif dan efisien.

\section{Strategi Pembelajaran Mata Kuliah Kewirausahaan di PTAIN Jawa Timur: Perspektif Pengelolaan Pembelajaran.}

Temuan penelitian dalam masalah pengelolaan pembelajaran mata kuliah kewirausahaan di PTAIN Jawa Timur meliputi penciptaan ketertarikan berpikir mahasiswa terhadap fenomena yang terjadi dalam kehidupan tentang kewirausahaan untuk penguatan wawasan terhadap materi yang akan disampaikan, hal ini dilakukan sebelum memasuki materi. Demikian juga halnya setelah pembahasan materi, pengajar mengakhiri pembelajaran dengan pemberian soal-soal tertulis ataupun tugas-tugas individu /kelompok untuk lebih memahami kandungan materi yang telah disampaikan. Pemantauan kemajuan belajar mahasiswa juga dilakukan melalui pemberian soal-soal tertulis ataupun tugas-tugas individu/kelompok dengan lingkup materi yang sudah dijelaskan untuk lebih memahami lingkup materi tersebut. Demikian juga yang dilakukan pengajar dalam hal pengontrolan belajar mahasiswa yaitu melalui pemberian soal-soal tertulis ataupun tugas individu/kelompok tadi untuk selanjutnya dilakukan evaluasi.

Penciptaan ketertarikan berpikir mahasiswa, kemudian pemberian soal-soal tertulis ataupun tugas-tugas individu/kelompok tersebut dapat dijadikan suatu motivasi untuk pembelajaran materi-materi yang dipelajari. Di samping itu juga, penciptaan ketertaikan berpikir mahasiswa ataupun pemberian soal-soal tertulis dan tugas individu/kelompok tersebut digunakan sebagai alat penataan interaksi antara mahasiswa dengan pengajar.

Temuan penelitian yang serupa juga ditemukan dalam buku-buku literatur Kewirausahaan, diantaranya Wiratmo (1995) dalam literatur "Pengantar Kewiraswastaan", Kerangka Dasar Memasuki Dunia Bisnis" di mana sebelum memasuki materi yang dibahas terlebih dahulu dilakukan pengantar materi untuk memberikan penguatan wawasan materi dan diakhiri pembahasan pokok bahasan-pokok bahasan dengan uji pemahaman-uji pemahaman berupa soal-soal tertulis.

Dengan demikian, pembahasan temuan hasil penelitian mengenai pengelolaan pembelajaran mata kuliah kewirausahaan di PTAIN Jawa Timur dapat disimpulkan bahwa pengelolaan motivasional belajar mahasiswa terhadap pokok bahasan-pokok bahasan dan materi mata kuliah dan penataan interaksi antara pengajar dan mahasiswa dilakukan melalui penciptaan ketertarikan berpikir mahasiswa terhadap fenomena yang terjadi pada saat memulai pembelajaran mata kuliah dan memberikan soal-soal tertulis ataupun tugas individu/kelompok pada saat menutup pembelajaran mata kuliah. Jenis penciptaan ketertarikan berpikir mahasiswa yang digunakan yaitu dengan memberikan cerita/contoh tentang orang/lembaga/negara yang berhasil/gagal dalam proses pelaksanaan kewirausahaannya. Jenis pemberian soal-soal tertulis ataupun tugas individu/kelompok berhubungan dengan penggalian sumber literatur yang dianjurkan untuk diringkas yang selanjutnya dievaluasi. 


\section{KESIMPULAN DAN SARAN \\ Kesimpulan}

Berdasarkan temuan penelitian dan pembahasan hasil penelitian tentang Aplikasi Pendidikan Kewirausahaan (Perspektif Strategi Pembelajaran Mata Kuliah Kewirausahaan di PTAIN Jawa Timur) dapat ditarik beberapa kesimpulan sebagai berikut bahwa dalam Strategi Pembelajaran Mata Kuliah Kewirausahaan di PTAIN Jawa Timur menggunakan model konvensional/tradisional yaitu menggunakan metode ceramah dalam mentransfer ilmu kepada mahasiswa untuk memberikan informasi. Tentunya, metode tersebut sangat belum memadai bila melihat penyebaran pokok bahasan dalam silabus yang dikaitkan pula dengan teknik/metode mengajar yang ditawarkan. Pengajar mata kuliah Kewirausahaan di PTAIN Jawa Timur mengikuti urutan pokok bahasan-pokok bahasan dalam silabus. Pengajar mata kuliah membuat ringkasan isi materi secara tertulis dan tidak digandakan untuk disebar luaskan, tetapi didiktekan (bila perlu).

Dalam pemyampaian pembelajaran mata kuliah Kewirausahaan di PTAIN Jawa Timur, pengajar memulai pembelajarannya dengan menciptakan ketertarikan berpikir mahasiswa untuk penguatan wawasan melalui fenomena-fenomena yang terjadi dalam kehidupan masyarakat tentang kewirausahaan, seperti cerita/contoh orang/lembaga/negara yang berhasil/gagal dalam pelaksanaan kewirausahaannya. Selanjutnya, menutup pembelajaran dengan memberikan soal-soal tertulis ataupun tugas-tugas individu/kelompok melalui penggalian sumber literatur untuk diringkas dan dievaluasi. Media yang digunakan adalah orang (pengajar) yang didukung oleh buku-buku literatur dengan metode ceramah atau diskusi. Pengelolaan motivasional mahasiswa terhadap pokok bahasan-pokok bahasan mata kuliah kewirausahaan dan penataan interaksi antara pengajar dan mahasiswa dilakukan melalui penciptaan ketertarikan berpikir mahasiswa dengan cerita/contoh/orang/lembaga/negara yang berhasil/gagal dalam kewirausahaan pada saat memulai pembelajaran dan menutup pembelajaran melalui pemberian soal-soal tertulis dan tugas individu/kelompok pada mahasiswa dengan penggalian sumber literatur untuk diringkas dan dievaluasi.

\section{Saran}

Pembelajaran mata kuliah Kewirausahaan di PTAIN Jawa Timur dengan model konvensional/tradisional tersebut hendaknya lebih dapat memotivasi mahasiswa belajar yaitu dengan penampilan pengajar yang dapat menciptakan suasana yang lebih segar dan tidak jenuh dalam arti adanya selingan berupa humor/anekdot, sehingga tidak terkesan menonton, kaku dan otoriter yang hanya cenderung menggunakan metode ceramah. Oleh karena itu berbagai alternatif penggunaan metode pembelajaran dan tujuan yang mungkin dicapai dapat dieksperimenkan untuk dikembangkan. (lebih lanjut dapat dilihat pada lampiran 13).

Jika pembelajaran mata kuliah Kewirausahaan menggunakan media orang (pengajar), maka diupayakan pengajar hendaknya memiliki daya pribadi yang mempesona dalam arti dapat menciptakan suasana segar dan tidak jenuh bagi mahasiswa dengan selingan humor/anekdot, sehingga tidak terkesan monoton. Jika hal ini tidak dilakukan, maka dimungkinkan akan terjadi sebaliknya, yaitu mahasiswa akan pasif dan kurang perhatian. Oleh karena itu berbagai alternatif penggunaan media pembelajaran dan untung rugi penggunaannya dapat dieksperimenkan (Penciptaan ketertarikan berfikir mahasiswa melalui cerita/contoh tentang fenomena kewirausahaan yang terjadi pada saat 
memulai pembelajaran mata kuliah dan juga pemberian soal-soal tertulis atau tugas individu/kelompok melalui penggalian sumber literatur untuk diringkas pada saat menutup pembelajaran mata kuliah perlu tetap dipertahankan oleh pengajar dan bila perlu polanya lebih ditingkatkan dengan lebih banyak mahasiswanya yang aktif di dalam kelas untuk memecahkan persoalan-persoalan yang berkaitan dengan pelaksanaan kewirausahaan melalui pendekatan studi kasus yang sifatnya problem based learning (belajar berdasarkan masalah). Pengorganisasian isi materi mata kuliah Kewirausahaan yang berupa ringkasan yang ditulis tangan tersebut perlu disebar luaskan pada mahasiswa sebagai bahan tambahan untuk dipelajari. Selanjutnya pengorganisasian silabus mata kuliah Kewirausahaan di PTAIN Jawa Timur yaitu urutan pokok bahasan-pokok bahasan yang ada perlu diupayakan untuk dimodofikasi. Oleh karena itu salah satu alternatif pengorganisasian silabus Mata Kuliah Kewirausahaan versi "Alma" sebagai panduan perkuliahan dapat dieksperimenkan untuk dikembangkan 


\section{DAFTAR RUJUKAN}

Alma, Buchari, 1999, Kewirausahaan, Bandung: Alfabeta.

Asy'ari, Musa, Islam,1996, IAIN dan Pengembangan Kewirausahaan, Journal on Islamic Studies, Yogyakarta: Al-Jami'ah, No. 59, ISSN, No. 0126, 012 X, IAIN Sunan Kalijata.

Bogdam,R.C. dan Biklen, S.K., 1982, Qualitative Research for Education An Introduction to Theory and Methods. London:Allyn And Bacon, Inc.

Danandjaya, Foklor Indonesia, 1984. Ilmu Gosip, Dongeng dan lain-lain, Jakarta: Grafiti Press.

Degeng, I Nyoman dan Miarso, Y. Hadi, 1990, Buku Pegangan Teknologi Pendidikan: Terapan Teori Kognitif dalam Desain Pembelajaran, Jakarta: UT.

Degeng, I Nyoman, S., 1989, Ilmu Pengajaran: Taksonomi Variabel, Jakarta: Depdikbud, Dikti, Proyek P2LPTK.

Esseft, J.V. dan Essef, Mary, S., 1980, Selection Media and Material, Workbook on Developing Individualized Indructional, London: Educational System for the Future.

Gagme, R.M., 1985, The Conditional of Learning, New York: Holt Rinehart and Einston.

Indrus, M. Syafei, 1999, Strategi Pengetahuan Kewirausahaan dan Peranan Perguruan Tinggi Dalam Rangka Membangun Keunggulan Bersaing Bangsa Indonesia pada Milenium Ketiga, PPS UMM Malang, Malang.

Lupiyoadi, Rambat dan Wacik, Jero. 1998, Wawasan Kewirausahaan, Cara Mudah Menjadi Wirausaha, Jakarta: LPFE Universitas Indonesia.

Martin, R dan Briggs, 1985, Principle of Instructional Design, New York: Holt Rinehart and Winston.

Miles, M.B. dan Huberman, A.M., 1984, Qualitative Data Analysis, California: Sage Publication Inc, Baverly Hill.

Moleong, L.J, 1990, Metodologi Penelitian Kualitatif, Bandung: Remaja Karya.

Muhadjir, N, 1989, Metodologi Penelitian Kualitatif, Yogyakarta: Rana Sarusin.

Natsir, Nanat Fatah, 1999, Etos Kerja Kewirausahaan Muslim, Bandung: Gunung Jati Press.

Owens, R.G., 1982, Organization Behavior in Education, London: Prentice Hall, Inc.

Patton, M.Q., 1980, Qualitative Evaluation Methods, California: Sage Publication Inc, Baverly Hills.

Reigeluth, C.M. dan Merril, M.D. 1977, Classes of Intructional Variable Eduational Technology. London: Journal of Introctional Development, 2/Vol. III.

Reigeluth, C.M. dan Merril, M.D. 1978, A Knowledge Base for Improving Our Methods of Intruction. London: Educational Psychologist.

Reigeluth, C.M., 1979, In Search of Better What to Organize Instruction: The Elaboration Theory, London: Journal of Introctional Development, 2/Vol. III.

Reigeluth, C.M, Instructional Design: What is it? And Why Is it? Dalam Reigeluth, C.M. (ed.): 1983, Instructional Design Theorist and Models: An Overview of Their Current Status. London: Lawrence Ealbaum Association Publishers.

Schumpeter, J.A., 1971, The Theory of Operasional Entrepreneurship Education, Bandung: Bumi Aksara.

Soegiyanto, S. 1989, Penelitian Kualitatif: Teori dan Aplikasi, Surabaya: Makalah Penataran Penelitian Dosen IKIP Surabaya, Puslit IKIP.

Soemanto, Wasty. 1994, Pendidikan Wiraswasta, Jakarta: Bumi Aksara.

Spradly, 1979, Partisipant Observation. New York: Holt Rinehart and Winston. 
Sutopo, Agustus 1998, Konsep-konsep Dasar Dalam Penelitian Kualitatif, Surakarta: Makalah Seminar Nasional Penelitian Dosen FKIP/UNS.

Wiratmo, Masykur, 1995, Pengantar Kewirausahaan, Kerangka Dasar Memasuki Dunia Bisnis, Yogyakarta: Edisi Pertama, BPFE Universitas Gadjah Mada. 